\title{
Hyperbolic Discounting and the Phillips Curve
}

\author{
Liam Graham*and Dennis J. Snower ${ }^{\dagger}$
}

14 May 2007

\begin{abstract}
Using a standard dynamic general equilibrium model, we show that the interaction of staggered nominal contracts with hyperbolic discounting leads to inflation having significant long-run effects on real variables.
\end{abstract}

JEL Classification: E20, E40, E50

Keywords: inflation, unemployment, Phillips curve, nominal inertia, monetary policy, dynamic general equilibrium

\section{Introduction}

In this paper we show that if households have hyperbolic preferences and face staggered nominal wage contracts, inflation (via money growth) has significant long run effects on output and employment. With our baseline calibration, which takes the length of the contract period to be 1 year, a permanent increase in inflation of $1 \%$ is associated with an increase in output and employment of approximately $0.2 \%$ for inflation rates of up to around $10 \%$. This is roughly of the same order of magnitude as the empirical estimates of the long-run Phillips curve in the well-known studies that have found a significant tradeoff, extending from the early contributions of Phillips (1958) and Samuelson and Solow (1960) to the recent work of Akerlof, Dickens and Perry (1996, 2000), Fair (2000) and many others. Blanchard and Fisher (1989) wrote: "Most economists who came to accept the view that there was no long-run trade-off between inflation and unemployment were more affected by a priori argument than by empirical evidence." We challenge the "a priori" arguments that the long-run Phillips curve is necessarily vertical.

\footnotetext{
${ }^{*}$ Corresponding author: Department of Economics, University College London, Gower Street, London WC1E 6BT, UK. Liam.Graham@ucl.ac.uk

${ }^{\dagger}$ Institut für Weltwirtschaft, Düsternbrooker Weg 120, 24105 Kiel, Germany. Tel: +49 431 8814 236; fax: +49 4318814 501; email: D.Snower@ifw-kiel.de
} 
There are wide implications for macroeconomics and macroeconomic policy. If money is no longer superneutral, unemployment cannot be decomposed into cyclical and structural components; the concepts of an NRU or NAIRU need to be reconsidered. A wide econometric literature identifies supply and demand shocks by a decomposition into permanent and transient effects. This too becomes questionable if inflation has permanent effects on real variables. In terms of policy, the presence of a non-vertical Phillips curve adds an extra degree of complexity to the policymaker's task.

Our model is a standard dynamic general equilibrium model with staggered nominal contracts. Our only unconventional assumption is that households have hyperbolic preferences. Instead of a constant rate of time preference, we model households as showing a strong preference for a payoff today over a payoff tomorrow, but a much weaker preference for a payoff in a year's time over a payoff in a year and a day's time. Our analysis here rests heavily on the seminal work of Laibson (1996) and Barro (1999).

There are three channels by which inflation has long-run effects on real variables in our model:

(i) The employment cycling effect: As inflation increases, relative prices become more volatile and thus the price allocation system works less efficiently. Our analysis captures this phenomenon through fluctuations in real wages, since nominal wages are constant over the contract period while the price level rises continually in an inflationary steady state. The greater the inflation rate, the more volatile real wages and employment become. Since this employment cycling (firms substituting towards labor with relatively low real wages) is inefficient, the productivity of labor falls, reducing labor demanded and output supplied.

(ii) The labor smoothing effect: When households have a preference for smoothing their labor services through time, employment cycling increases their disutility of labor, thereby inducing households to reduce their labor supply.

(iii) The discounting effect: Time discounting reduces the weight of households' future disutility of labor. If nominal wages are constant over the contract period, more inflation means a greater fall in real wages, and a greater rise in employment and the disutility of labor over the contract period. The more the future disutility of labor is discounted, the less onerous labor becomes and the more labor is supplied.

Whereas the first and second effects generate a negative relation between inflation and macro activities (aggregate employment and output), the third gives rise to a positive relation. We show that the discounting effect dominates for inflation rates less than 10 percent. 
That discounting leads to a non-vertical Phillips curve in new Keynesian models is well-known ${ }^{1}$, however with the discount factor pinned down by the real interest rate, the effect remains small (Ascari, 1998, Graham and Snower, 2003). A model with hyperbolic discounting has agents discounting payoffs in the near future at a very high rate (discount factors of $60 \%$ or $70 \%$ are common in the literature) while matching the observed real interest rate (Barro, 1999 refers to this as "observational equivalence"). It is these high discount factors which apply to the wage setting decision, so our model significantly amplifies the discounting effect.

Our calibrations indicate that, with hyperbolic discounting, the discounting effect is dominant at inflation rates less than $10 \%$. Thus the relation between inflation (on the one hand) and employment and output (on the other) is significantly upward-sloping over this range.

The paper is organized as follows. Section 2 deals with preliminaries: the relation of our analysis to the literature and a discussion of our central assumption: hyperbolic discounting. Section 3 presents our model and its calibration. Section 4 gives some results along with sensitivity analysis to key parameters. In section 5 we discuss the key assumptions of fixed contract length and no indexation. Section 6 concludes.

\section{Preliminaries}

\subsection{Relation to the Literature}

Our analysis relates to the existing literature in two distinct ways. First, the numerical results of our model are derived from calibrated parameters that are standard in the New Phillips Curve models. Our only novel assumption in this context is hyperbolic discounting, and our calibrations in that respect are standard as well. Second, our results are in line with a growing body of empirical macroeconomic evidence.

The existing empirical evidence on the slope of the long-run Phillips curve has been mixed for some time, and has led major contributors such as Mankiw (2001) to be "agnostic" on the issue. Given economists' predilection for the

\footnotetext{
${ }^{1}$ Such a discounting effect is present in the new Keynesian Phillips curve based on Calvo pricing

$$
\pi_{t}=\beta E_{t} \pi_{t+1}+\lambda y_{t}
$$

which implies a relation between output and inflation in the vicinity of the zero-inflation steady state

$$
y=\frac{1-\beta}{\lambda} \pi
$$
}


classical dichotomy, it is striking how many empirical studies reject it. In recent years, there has been a rapidly growing literature finding empirical evidence for a long-run tradeoff between inflation and macroeconomic activity.

Ball (1997) shows that countries experiencing large and long declines in inflation tend also to encounter comparatively large increases in their NAIRUs. Ball (1999) suggests that such a relationship may be due to monetary policy: countries with relatively contractionary policy in the 1980s tended to have relatively large increases in their NAIRUs. Akerlof, Dickens and Perry (1996, 2000), looking at data for the US find empirical evidence of a long-run tradeoff at low inflation rates. Lundborg and Sacklen (2001) apply a small open-economy version of this model to Swedish data and find a negative long-run relationship between inflation and unemployment.

Dolado, López-Salido and Vega (2000) find some evidence of a permanent tradeoff over the entire inflation range for Spain using a data set running from 1964 - 1995. Fisher and Seater (1993) and Fair (2000) find long-run tradeoffs as well. King and Watson (1994) find that the estimated long-run tradoff depends on short-run identification assumptions. Ericsson, Irons and Tryon (2001) find a positive long-run relation between output and inflation for most G-7 countries. Gottschalk and Fritsche (2005) find a strong negative correlation between the trend components of inflation and unemployment for West Germany. Schreiber and Wolters (2005) use a VAR cointegration analysis to find a negative long-run relation between inflation and unemployment for Germany, robust with respect to specification variations. For post-WWII data of the Canadian economy, Koustas (1998) and Koustas and Voloce (1996) find that the evidence strongly rejects the vertical long-run Phillips curve. Furthermore, using data covering the last 30-40 years for Austria, Denmark, Finland, France, Germany, Italy, Spain, Sweden and the UK, Koutas and Serletis (2003) present evidence against a vertical long-run Phillips curve.

An important strand of the recent literature seeks to derive the Phillips curve tradeoff from structural macro models, arguing that the traditional singleequation models cannot fully capture the various important causal relations underlying the Phillips curve. Bullard and Keating (1995) use a structural VAR to estimate the long-run response of output to a permanent increase for a group of 16 countries. There point estimates of the response are positive for 10 countries in the sample. Of these, the responses are significantly different from zero at a $90 \%$ confidence interval for 5 countries (including the UK, Austria and Germany), and at a $5 \%$ confidence level for 2 more (Japan and Spain). Ahmed and Rogers (1998) find long-run effects of inflation on consumption, investment and 
output are positive, on the basis of 100 years of U.S. data. ${ }^{2}$ In the context of a small structural rational expectations model, Coenen, Orphanides and Wieland (2004) show how a zero bound on nominal interest rates a positive relation between inflation and the output gap at low inflation rates. Karanassou, Sala and Snower $(2003,2005)$ find evidence of a significant negative relation between inflation and unemployment in the context of estimated labor market systems for the U.S. and the E.U.

Our analysis contributes to a larger theoretical literature rationalizing a longrun tradeoff between inflation and macro activity. It is well-known that the superneutrality result of Sidrauski (1967) depends on a number of strong assumptions, such as the separability of consumption and leisure in utility. The long-run effect of money growth on macro activity can be shown to depend on the nature of household preferences and the role of money in the economy (Orphanides and Solow (1990) provide a survey). This suggests that the slope of the long-run Phillips curve is not necessarily vertical and its sign is an empirical issue. Our rationale for the long-run Phillips curve, by contrast, does not rest on non-separable utility functions, cash-in-advance, or money in the production function.

Several authors (e.g. Ascari (2000, 2003) have shown that the Phillips curve derived from New Keynesian microfoundations is highly nonlinear, with a positive relation between inflation and macro activity at low inflation rates and a negative relation at high inflation rates. In contrast to our analysis, however, the discounting effect is not strong in these models

In the context of a state-dependent menu cost model, Benabou and Konieczny (1994) show how the long-run Phillips curve tradeoff depends on the asymmetry of the profit function, the convexity of the product demand function, and discounting. Konieczny (1990), Kuran (1986) and Naish (1986) provide nonneutrality results in a broadly similar vein. Our model, by contrast, has timedependent nominal rigidities.

Our analysis is in some respects similar to the work of Akerlof, Dickens and Perry $(1996,2000)$ who show that the Phillips curve becomes downward sloping at inflation rates below $3-4 \%$ when there are departures from rational expectations or permanent nominal rigidities. In contrast, we show that the long run tradeoff exists with rational expectations and only temporary nominal rigidities. Our analysis is observationally distinct from that of Akerlof et al.

\footnotetext{
${ }^{2}$ Specifically, they estimate the effects of exogenous changes in the long-run component of inflation on aggregate consumption, investment and output, in the context of a fully identified structural vector error correction model.
} 
(1996), since our calibrations (below) imply a positive tradeoff between inflation and macroeconomic activity even when inflation is substantially higher than 3-4 percent.

Further rationales for a long-run Phillips curve tradeoff are given by Holden (2003) and Hughes-Hallett (2000). Holden (2003) shows how a non-superneutrality of money can arise at low inflation rates when the nominal wage can be changed only by mutual consent in wage negotiations. Hughes-Hallett (2000) shows how a long-run tradeoff between inflation and macroeconomic activity can arise through aggregation over sectoral / regional Phillips curves with heterogenous short-run slopes. Our analysis does not rely on such strategic considerations or aggregation issues.

\subsection{Hyperbolic discounting}

The assumption of a constant rate of time preference is generally adopted for analytical convenience, but a convincing underlying rationale for it has not been articulated, ${ }^{3}$ and it is at odds with the available empirical evidence which suggests that rates of time preference, viewed from the present moment, are high in the short run but much lower in the long run. ${ }^{4}$ For example, people much prefer $\$ 1000$ today than that sum in a month from now, while their relative valuation is much more evenly balanced when they have to choose between $\$ 1000$ in a year from now versus that sum in a year and a month. The observed time-varying discount rates can be captured by hyperbolic discount functions, in which events in $\tau$ periods are discounted with factor $(1+\alpha \tau)^{-\gamma / \alpha}$, where $\alpha$ and $\gamma$ are positive constants. ${ }^{5}$

When discount rates vary through time, households have a time - inconsistency problem: households make their current decisions on the basis of preferences displaying low time discount rates for intertemporal choices lying in the distant future; but once the future becomes the present, these households have a much higher degree of impatience. Such time inconsistent preferences can be modeled with standard game-theoretic tools as an intra-personal game, in which today's self is an independent player from each of the future selves. Today's self maximizes its utility, from today onwards into the future, knowing that the

\footnotetext{
${ }^{3}$ Axiomatic derivations are given by Koopmans (1960) and Fishburn and Rubinstein (1982).

${ }^{4}$ See, for example, Ainslie (1992), Loewenstein and Thaler (1989), and Loewenstein and Prelec (1992). Strotz (1956) was the first economist to study the implications of discount rates that decrease with the time horizon.

${ }^{5}$ See Loewenstein and Prelec (1992). Simpler hyperbolic discount functions, such as $1 / \tau$ and $1 /(1+\alpha \tau)$, are used in the psychology literature (e.g. Chung and Herrnstein (1961) and Ainslie (1992)).
} 
future selves will make decisions based on different preferences. The decisions of today's self affects the future selves; in particular, today's consumption determines the wealth that will be bequeathed to the future selves. Also, the decisions of the future selves affect today's self; in particular, future consumption affects the utility of today's self, because today's self maximizes its utility over the present and future. The equilibrium of the intertemporal game played among a household's selves is a Nash equilibrium, based on this intertemporal consistency of behaviors of the household's selves.

There is a rapidly growing literature that uses time-varying discount rates to explain a wide variety of other economic behaviors, including procrastination, retirement saving, self-deception, self-control, etc. ${ }^{6}$.

A key feature of hyperbolic preferences is "observational equivalence" (Barro, 1999): in a model with hyperbolic discounting the effective rate of time preference (after solving for the Nash equilibrium of the household) is constant and the discounting parameters can be chosen in such a way as to match observed values of the real interest rate.

\section{The Model}

We present a simple dynamic general equilibrium model consisting of three types of agent: households, firms and a government.

There is a continuum of households which supply differentiated labour to firms, consume goods, and hold money balances and bonds. Each household sets its nominal wage, given the demand for its services. In the spirit of Taylor (1979), we group households into $N$ wage-setting cohorts, each of which sets a nominal wage contract for $N$ periods. Different cohorts set wages at different times, uniformly staggered ${ }^{7}$.

Firms produce a homogeneous consumption good through differentiated labour. The government prints money and real bonds, and rebates the seigniorage proceeds to households as a lump sum.

\footnotetext{
${ }^{6}$ See, for example, Akerlof (1991), Benabou and Tirole (2002, 2004), Carrillo and Marriotti (2000), Diamond and Koszegi (2003), and O’Donoghou and Rabin (1999a,b), Laibson, Repetto, and Tobacman (2001)

${ }^{7}$ Another possibility, and one widely used in the literature, is to use Calvo contracts. However for sufficiently high levels of money growth, Calvo contracts are not appropriate. The reason is straightforward. With Calvo contracts, some households keep their nominal wage unchanged for a very long period of time, which means that, in the presence of inflation, the real value of this wage approaches zero. This implies that the firm will wish to hire as much of the labor of these households as possible, and as little of the other households. This is very inefficient so output approaches zero. Bakshi et al (2002) report that this happens with inflation of 5.5\%; Ascari (2003) at somewhat higher levels.
} 


\subsection{Firms}

The representative firm uses all types of labour in a production function with a constant elasticity of substitution (Dixit and Stiglitz (1977)) to produce a homogenous consumption good, and all labour types enter the production function symmetrically: ${ }^{8}$

$$
y_{t}=\left[\int_{h=0}^{1} l_{t}(h)^{\frac{\theta-1}{\theta}} d h\right]^{\frac{\theta}{\theta-1}}
$$

where $y_{t}$ is output, $l_{t}(h)$ is the amount of labour chosen from household $h$, and $\theta$ is the elasticity of substitution between different labour types.

There is perfect competition in the product market. The firm's cost-minimization implies a standard demand function for each household's labour:

$$
l_{t+i}(h)=\left(\frac{\mathrm{W}_{t}(h)}{\mathrm{W}_{t+i}}\right)^{-\theta} y_{t+i}: 0<i<N-1 ; t=k N
$$

where $\mathbf{W}(h)$ is the wage set by household $h$ and the aggregate wage index in terms of efficiency labour is

$$
\mathrm{W}_{t}=\left[\int_{h=0}^{1} \mathrm{~W}_{t}(h)^{1-\theta} d h\right]^{\frac{1}{1-\theta}}
$$

Given that firms are perfect competitors their markup will be zero so that the real wage is constant and equal to unity $\mathrm{W}=\mathrm{P}$.

\subsection{Households}

Households consume, supply differentiated labour and hold money balances and bonds. A household $h$, which resets its wage in period $t$, faces a budget constraint in that period given by:

$$
\begin{aligned}
& c_{t}(h)+\frac{\mathrm{M}_{t+1}(h)}{\mathrm{P}_{t}}+\frac{\mathrm{B}_{t+1}(h)}{\mathrm{P}_{t}} \\
= & (1-\tau(h)) \frac{\mathrm{W}_{t}(h)}{\mathrm{P}_{t}} l_{t}(h)+\frac{\mathrm{T}_{t}(h)}{\mathrm{P}_{t}}+\frac{\mathrm{M}_{t}(h)}{\mathrm{P}_{t}}+R \frac{\mathrm{B}_{t}(h)}{\mathrm{P}_{t}}
\end{aligned}
$$

${ }^{8}$ We use the following notational
\begin{tabular}{|l|l|l|}
\hline & nominal & real \\
\hline trended & $\mathrm{X}_{t}$ & $\mathrm{x}_{t}$ \\
\hline detrended & $X_{t}$ & $x_{t}$ \\
\hline steady state & $X$ & $x$ \\
\hline
\end{tabular}


where $c_{t}$ is consumption, $\mathrm{W}_{t}$ the nominal contract wage, $\mathrm{M}_{t}$ nominal money holdings, $\mathrm{P}_{t}$ the aggregate price index, $R$ the gross real interest rate (assumed constant) on bond holdings $\mathrm{B}_{t}, \mathrm{~T}_{t}$ net lump-sum transfers from government and $\tau(h)$ an income tax which we will allow to vary across households. The left-hand side represents spending on consumption and closing real money balances and bonds; the right hand side represents income from labour, profits and opening bond and money holdings net of taxes.

Household preferences are given by

$$
U_{t}(h)=u\left(c_{t}(h), l_{t}(h), m_{t}(h)\right)+\gamma \sum_{i=1}^{\infty} \delta^{i} u\left(c_{t+i}(h), l_{t+i}(h), m_{t+i}(h)\right)
$$

where $m_{t}(h)=\frac{\mathbf{M}_{t}(h)}{\mathrm{P}_{t}}$ are the household's real money balances.

Following Laibson (1996) and much of the subsequent literature, for analytical convenience we have approximated the hyperbolic discount function by a "quasi-hyperbolic" discount function in which the discount factors from the perspective of the current period are $1, \gamma \delta, \gamma \delta^{2}, \gamma \delta^{3} \ldots$. The discount factor between the first two periods is $\gamma \delta$; but that between all subsequent periods is $\delta$. Thus we can think of $\gamma$ as a short-run discount factor, and $\delta$ as a long-run discount factor.

We choose a single-period utility function that has desirable long-run properties (see King, Plosser and Rebelo (1988)):

$$
u\left(c_{t}(h), l_{t}(h), m_{t}(h)\right)=\log c_{t}(h)+\zeta_{l} \frac{\left(1-l_{t}(h)\right)^{1-\eta}-1}{1-\eta}+\zeta_{m} \log m_{t}(h)
$$

and assume the household writes nominal wage contracts which last for $N$ periods $^{9}$.

When the discount rate is time-varying, the household's behavior is timeinconsistent: in future periods the household will have an incentive to change plans made in the current period. Since household cannot commit itself to a plan beyond the current period and since a household with rational expectations will take this into account when making its decisions, it is standard practice (e.g. Laibson, 1996) to formulate the household's problem as a game played by the household at time $t$ (self $t$ ) against the household in future periods (future selves).

In the appendix, we show that the unique equilibrium strategy $s_{t}(h)$ in this

\footnotetext{
${ }^{9}$ We do not allow indexation within the contract period. We disucss the empirical plausibility of this assumption in section 5 .
} 
game of a household with preferences given by (5) facing constraints (4) and (2) is a choice of consumption $c_{t}(h)$, real money balances $m_{t}(h)$, and, at the start of each contract period, a choice of the nominal wage $\mathbf{W}_{t}(h)$ to be kept fixed for the next $N$ periods,

$$
\begin{aligned}
& s_{t}(h)=\left\{c_{t}(h), m_{t}(h)\right\}: t \neq k N \\
& s_{t}(h)=\left\{c_{t}(h), \mathrm{W}_{t}^{*}(h), m_{t}(h)\right\}: t=k N
\end{aligned}
$$

where the nominal reset wage (i.e. the nominal wage at the beginning of the contract period) is given by

$$
\mathrm{W}_{t}^{*}(h)=\frac{\zeta_{l} \theta}{\theta-1} \frac{\left(1-l_{t}(h)\right)^{-\eta} l_{t}(h)+\gamma \sum_{i=1}^{N-1} \delta^{i}\left(1-l_{t+i}(h)\right)^{-\eta} l_{t+i}(h)}{\frac{1-\tau(h)}{c_{t}(h)} \sum_{i=0}^{N-1} R^{-i} \frac{l_{t+i}(h)}{\mathrm{P}_{t+i}}}
$$

consumption is equal to the annuity value of after-tax lifetime wealth

$$
c_{t}(h)=\frac{R-1}{R}(1-\tau(h))\left[\sum_{j=0}^{\infty} \sum_{i=j N}^{j(N-1)} R^{-i} \frac{\mathrm{W}_{t}^{*}(h)}{\mathrm{P}_{t+i}} l_{t+i}(h)+a_{0}(h)\right]
$$

and real money balances are given by

$$
m_{t}(h)=\left[\frac{1}{\zeta_{m} c_{t}^{*}(h)}\left(1-\frac{1}{R} \frac{\mathrm{P}_{t}}{\mathrm{P}_{t+1}}\right)\right]^{-\frac{1}{\nu}}
$$

\subsection{Aggregate quantities}

The government's budget constraint, in aggregate values, ${ }^{10}$ is

$$
\frac{\mathrm{B}_{t+1}}{\mathrm{P}_{t}}+\frac{\mathrm{M}_{t+1}}{\mathrm{P}_{t}}+\frac{\Theta_{t}}{\mathrm{P}_{t}}=R \frac{\mathrm{B}_{t}}{\mathrm{P}_{t}}+\frac{\mathrm{M}_{t}}{\mathrm{P}_{t}}-\frac{\mathrm{T}_{t}}{\mathrm{P}_{t}}
$$

where $\Theta_{t}$ is any net revenue from the income tax.

A resource constraint closes the model.

$$
Y_{t}=C_{t}
$$

\footnotetext{
${ }^{10}$ Note that the variables $\mathrm{B}_{\mathrm{t}}, \mathrm{M}_{t}$, and $\mathrm{T}_{t}$ are not to be confused with the household's holdings $\mathrm{B}_{\mathrm{t}}(h), \mathbf{M}_{t}(h)$, and $\mathbf{T}_{t}(h)$.
} 
We define aggregate labour as

$$
l_{t}=\int_{h=0}^{1} l_{t}(h) d h
$$

\subsection{Equilibrium}

A competitive equilibrium for the above economy is a sequence of plans for

- allocations of households $\left\{c_{t}^{*}(h), l_{t}(h), m_{t}(h), b_{t}(h)\right\}_{t=1: \infty}^{h=1: \infty}$

- prices $\left\{\mathrm{W}_{t}\right\}_{t=1: \infty}$

- aggregate labour input $\left\{l_{t}\right\}_{t=1: \infty}$

such that

1. Given prices, the allocations are Nash equilibria of the game-theoretic problem of each household (and hence solve the utility maximization problem)

2. $\left\{\mathrm{W}_{t}\right\}_{t=1: \infty}$ is the marginal product of aggregate labour

3. All markets clear

\subsection{The steady state}

For the remainder of the paper we consider the properties of a symmetric steady state in which all household behave identically. We can then think of our model as consisting of $N$ agents, one from each cohort. Each agent faces an identical problem so chooses the same wage (in real terms) when they can reset it. This means the present value of labour income over the contract period is the same for each agent, and (10) means that they each consume the same constant proportion of their lifetime wealth in each period. Although the present value of labour income over the contract is the same for every agent, the present value of lifetime wealth is slightly different since at the start of time, different cohorts start in different periods of their contracts with different incomes. We can choose the income tax rate to equalise the present value of lifetime wealth across cohorts, so all agents consume the same amount. Since each agent's path of income falls across the contract period, agents in different cohorts trade bonds to smooth consumption ${ }^{11}$.

\footnotetext{
${ }^{11}$ Were we to model off-steady state behaviour, we would need to invoke some form of consumption insurance to deal with the consequent heterogeneity as in, for example, Huang, Liu and Phaneuf (2004).
} 
In the steady state, the money growth rate is constant and equal to the rate of inflation $\pi$ :

$$
\pi=\frac{\mathrm{M}_{t+1}}{\mathrm{M}_{t}}
$$

The equation for the aggregate wage index (3) implies the steady state real contract wage is:

$$
\frac{W^{*}}{P}=\left(\frac{1}{N} \frac{1-\pi^{N(\theta-1)}}{1-\pi^{\theta-1}}\right)^{\frac{1}{\theta-1}}
$$

Combining (9) and (10) gives a labour supply relation for each household

$$
\left(1-l_{t}(h)\right)^{-\eta} l_{t}(h)+\gamma \sum_{i=1}^{N-1} \delta^{i}\left(1-l_{t+i}(h)\right)^{-\eta} l_{t+i}(h)=\frac{(\theta-1)(R-1)}{\zeta_{l} \theta}
$$

This sets the present value of the marginal disutility of labour with respect to the wage (on the left-hand side) equal to the present value of the marginal utility of the extra consumption resulting from a higher wage (on the right-hand side). Due to consumption smoothing, the right-hand side is constant since an increase in the wage leads one-for-one to an increase in consumption and thus a fall in its marginal utility.

Then (2), (16) and (17) fully describe the system and allow us to solve for output and aggregate employment.

This steady state satisfies condition (1) for an equilibrium by construction. Competitive factor markets ensure condition (2) holds and that the labour market clears. Given consumption of all households is identical, it is straightforward to show the goods market and bond market clears.

\subsection{Calibration}

We calibrate our model with standard values. For the elasticity of labour substitution, $\theta$, we choose a value of $5 .{ }^{12}$ We take the length of a contract to be one year, following Taylor (1998), and assume it remains constant as inflation varies. We discuss the empirical rationale for this in detail in section 5 . There are two wage-setting cohorts $(N=2)$, so that every six months one cohort sets its nominal wage and then keeps it fixed for a year. We take $\gamma$, the parameter measuring the size of short-run subjective discounting to be $70 \%$. Values of between $60 \%$ and $70 \%$ are standard in the hyperbolic discounting literature, for example Laibson (1996), based on empirical evidence such as Ainslie (1992). In

\footnotetext{
${ }^{12}$ Erceg et al (2000) use a value of 4; Huang and Liu (2002) use 6.
} 
the appendix we show that the three time preference parameters $\delta, \gamma$ and $R$ are related by

$$
\gamma=\frac{1-\delta}{\delta(R-1)}
$$

We set the annual real interest rate to $4 \%$, which, along with our value for $\gamma$, ties down the household's long-term discounting parameter, $\delta$, which is 0.986 . We take households' preferences over leisure to be logs, $\eta=1$. In Section 4.4 we analyze the sensitivity of our results to changes in all these variables.

We choose $\zeta_{l}$ to be 2.85 which gives, from (17), steady state labour of 0.22 corresponding to 48 weeks of 40 hours worked per year. The value of $\zeta_{m}$ affects the level of real money balances held by the household but since utility is separable in real money balances, this does not affect our results.

\section{Results}

Figure 1 shows how aggregate steady state employment and output changes with inflation. Both employment and output increase monotonically with inflation at approximately the same rate in the long run, though the output line lies everywhere below the employment line (for reasons elucidated below). Over the range of inflation analyzed, the relation is close to linear, with a $1 \%$ increase in inflation associated with a rise of approximately $0.2 \%$ in output and employment.

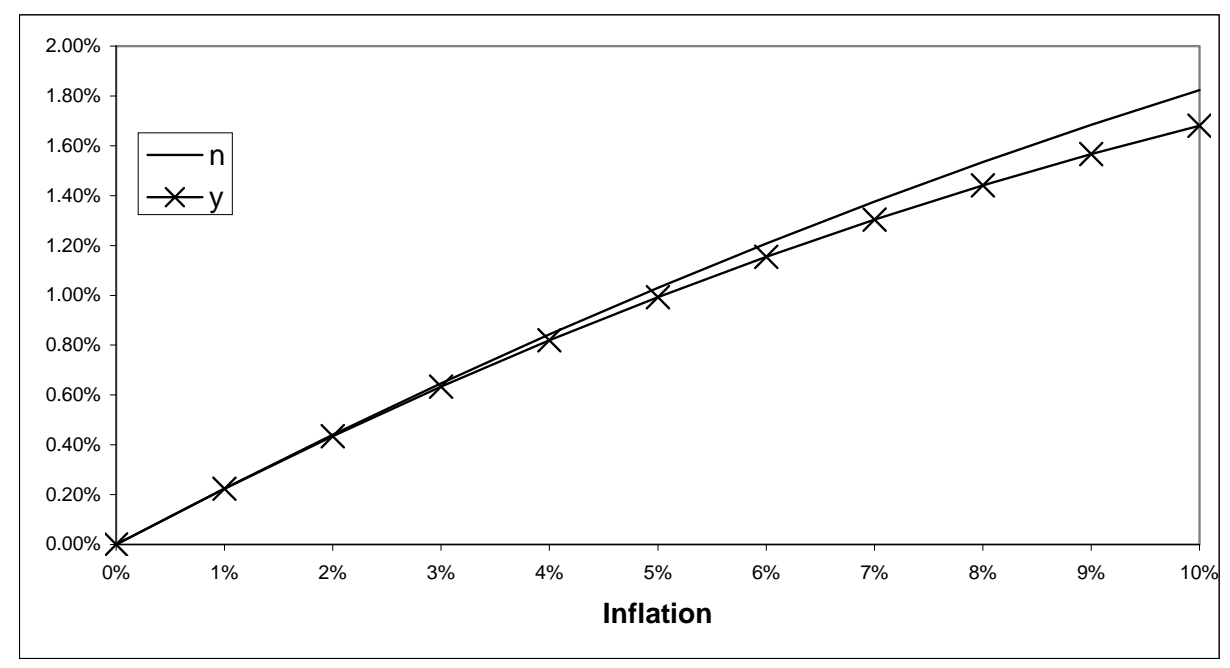

Figure 1: The steady state relation between real variables and inflation

$\mathrm{x}$-axis shows annualized inflation; $\mathrm{y}$-axis percent deviations of real variables from their values at zero-inflation 
There are three channels by which inflation affects real variables in this model which we call employment cycling, discounting and labour supply smoothing. We consider these in turn to explain the form of the Phillips curve in figure 1, and how this form depends on our chosen parameter values.

\subsection{Employment cycling}

For the two wage-setting cohorts $(N=2)$, let cohort 1 set its wage at time $t$ while cohort 2 sets its wage at time $t+1$ and each nominal contract wage is set for two periods. Suppose that steady-state inflation is positive. Since the price level rises from period to period whereas each cohort's nominal wage is readjusted every second period, it follows that each cohort's real wage is high at the beginning of its contract period and low at the end of it. Specifically, at time $t$, the real wage of cohort 1 is high and that of cohort 2 is low, and vice versa at time $t+1$. This is a simple way of capturing the empirical regularity that as inflation increases, relative prices become less stable.

Thus, the firm at time $t$ has a relatively low demand for cohort 1 and relatively high demand for cohort 2 , and vice versa at time $t+1$. This substitution towards labour types with low real wages (and away from labour types with high real wages) we call employment cycling. ${ }^{13}$. It is straightforward to show that the degree of employment cycling is a function only of the inflation rate and the degree of substitutability between different labour types

$$
\frac{l_{2}}{l_{1}}=\pi^{\theta}
$$

Since different labour types are imperfectly substitutable, employment cycling is inefficient in the sense that, for given aggregate employment $l$, more employment cycling is associated with lower aggregate output. The greater is

\footnotetext{
${ }^{13}$ At the levels of inflation relevant to our recent macroeconomic experience, the degree of employment cycling is quite small: at $2 \%$ inflation, employment fluctuates around its mean value by $2.5 \%$. But at $10 \%$ inflation this fluctuation rises to $16 \%$. In practice, employment cycling is of course much more likely to occur in form of hours variations than through hiring and firing. There is evidence that overtime work is sensitive to the wage, and thus it seems plausible that a limited degree of employment cycling may occur when a significant degree of inflation occurs over the contract period.

Furthermore, as is well known, it is straightforward to restate our model in terms of (a) heterogeneous firms, each employing a different labor type and each producing a different intermediate good and (b) firms producing a final goods by means of the imperfectly substitutable intermediate goods. In this context, employment cycling arises from substitutions among the different intermediate goods. These substitutions arise in response to variations in the relative prices of these goods and these price variations, in turn, are generated through staggered nominal wage setting. There is widespread evidence that large companies substitute among their intermediate good suppliers in response to cost variations, and it is clear that wage staggering can give rise to such cost variations.
} 
steady-state inflation rate, the more employment cycling firms do, and thus the lower the average productivity of labour. So output always increases by less than employment as inflation rises, and the output line lies below the employment line in figure 1. This captures the empirical regularity that as inflation increases, relative prices become less stable and this instability is a source of inefficiency.

Employment cycling is familiar from the new Keynesian literature on optimal monetary policy. For Woodford (2003) cycling between different types of labour is the key distortion which leads to a stabilising role for monetary policy.

\subsection{Labour smoothing}

The labour-supply smoothing effect occurs when $\eta$ is positive. Due to employment cycling, individual households cannot provide a constant stream of labour services through time. Since with nonzero $\eta$ the marginal disutility of labour rises with labour, these fluctuations in hours worked makes them worse off. In response, they supply less labour at a given wage over the contract period. Greater money growth leads to greater employment cycling, and thus lower average labour supply and, via the production function, lower output. In this way, the labour-supply smoothing effect weakens the steady-state employment-inflation tradeoff and, via the production function, the output-inflation tradeoff.

\subsection{Discounting}

The discounting effect may be understood intuitively through the following steps:

1. The labour supply relation (17), households set their contract wage so that the present value over the contract period of the marginal disutility of labor $(M D L)$ with respect to the wage is equal to the present value of the marginal utility of consumption $(M U C)$ from the labor income generated by a wage change.

2. When inflation is positive, labor supply increases over the contract period because of employment cycling and thus the $M D L$ increases over the contract period. By contrast, the $M U C$ remains constant through time, due to consumption smoothing.

3. Due to discounting, future marginal utilities and disutilities receive less weight than current ones. Since the $M D L$ increases over the contract period whereas the $M U C$ remains constant, an increase in discounting reduces the present value of the $M D L$ relative to the present value of the $M U C$. In response, the household raises its labor supply thereby raising 
the present value of the $M D L$ to bring the two present values back into equality. So, given inflation, as the discount rate increases, labour supply increases.

4. An increase in inflation means employment cycling gets stronger so the $M D L$ increases more over the contract period and the more the discounting effect reduces the present value of the $M D L$ relative to the present value of the $M U C$. Consequently the household increases its labor supply to bring the two present values back into equality. So, given discounting, as the inflation rate increases, labour supply increases.

Whereas the employment cycling effect and the labor smoothing effect generate an inverse relation between inflation and macro activity, the discounting effect generates a positive relation. For the calibration above, as Fig. 1 shows, the discounting effect is dominant for inflation rates less than 10 percent.

Barro (1999) showed that, in the absence of nominal contracting rigidities, an economy with hyperbolic discounting is observationally equivalent to one with exponential discounting in the sense that the equilibrium in an economy with hyperbolic discounters coincides with that in an economy with exponential discounters for a particular choice of the exponential discount factor. Our model depends on this observational equivalence with respect to the real interest rate, but observational equivalence is violated for other variables due to the existence of multi-period nominal contracts. To see this, note that the denominator of (9) is a flow of (marginal) income so is discounted exponentially, whereas the numerator is a flow of marginal utility, which is discounted at the subjective rate of time preference, i.e. hyperbolically. If contracts were only one period long $(N=1)$ - as is implicitly assumed in models without nominal contracting rigidities - neither the marginal disutility of labour nor the marginal utility of consumption would be discounted. However when $N>1$, the difference between the discounting of the denominator and the numerator breaks observational equivalence.

\subsection{Sensitivities}

For comparison, we first present the results of our model with standard exponential discounting. Figure 2 shows the trade-off between real variables and inflation for an exponential discount factor consistent with our choice of real interest rate. 


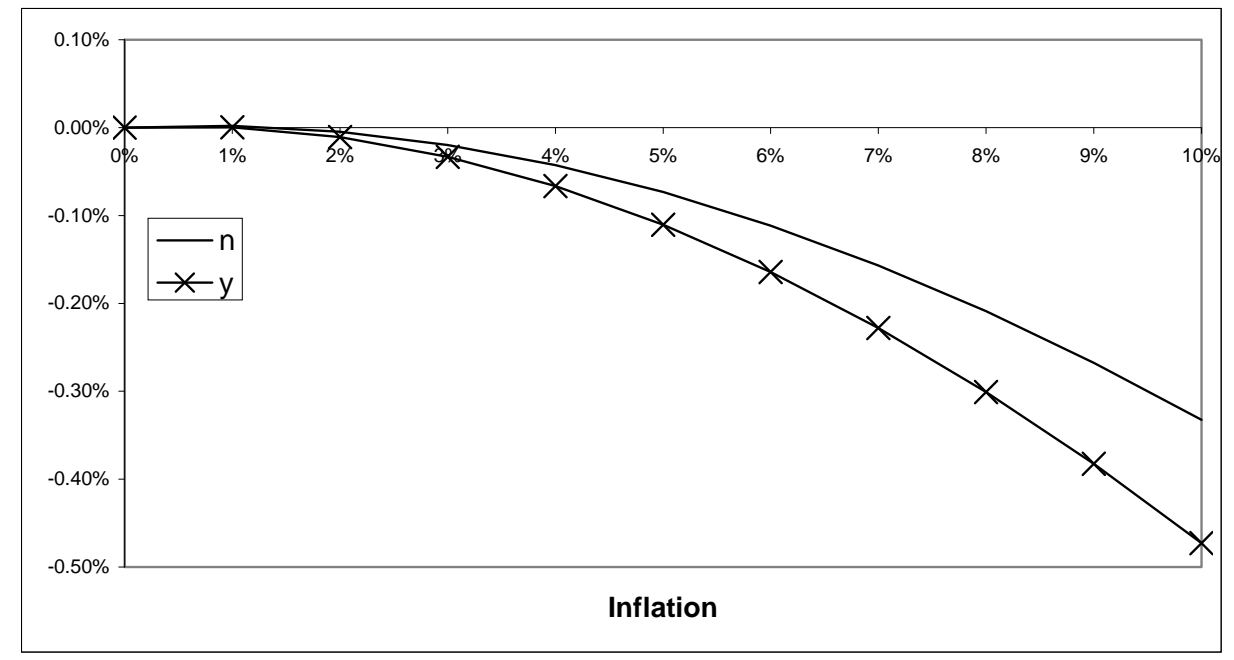

Figure 2: The steady state relation between real variables and inflation with exponential discounting

$\mathrm{x}$-axis shows annualized inflation; $\mathrm{y}$-axis percent deviations of real variables from their values at zero-inflation

With exponential discounting, the discounting effect is very weak and the other two effects, both of which lead to a negative relation between output and inflation, dominate.

Table 1 shows how the strength of the discounting effect, and hence the extent of the monetary non-superneutrality, varies with the size of the discount factor. The lower $\gamma$, the higher is the rate at which household's discount the future, so the stronger is the discounting effect and the greater is the long-run employment increase resulting from a given long-run rise in money growth. In the hyperbolic discounting literature, values of $60 \%$ and $70 \%$ for the short-term discounting parameter are common.

Table 1: Sensitivity to the short-run discount rate $\gamma$

\begin{tabular}{|l|l|l|l|l|}
\hline & $\pi$ increases from $2 \%$ to $3 \%$ & \multicolumn{2}{|c|}{$\pi$ increases from $6 \%$ to $7 \%$} \\
\hline$\gamma$ & Employment & Output & Employment & Output \\
\hline $90 \%$ & $0.05 \%$ & $0.05 \%$ & $0.02 \%$ & $0.00 \%$ \\
\hline $80 \%$ & $0.13 \%$ & $0.12 \%$ & $0.09 \%$ & $0.07 \%$ \\
\hline $70 \%$ & $0.21 \%$ & $0.20 \%$ & $0.17 \%$ & $0.15 \%$ \\
\hline $60 \%$ & $0.30 \%$ & $0.29 \%$ & $0.26 \%$ & $0.24 \%$ \\
\hline
\end{tabular}

Though we have assumed that there are only two wage-setting cohorts $(N=$ 2 ) to simplify our presentation, it is worth noting that using higher values has a 
negligible effect on our results. ${ }^{14}$

How does the tradeoff change with different values for $\eta$, the elasticity of intertemporal substitution of leisure? Figure 3 shows these tradeoffs for $\eta=$ 2 , the value used in Chari et al (1996) and for a higher value $\eta=5$. This contrasts with figure 1 in two ways. Firstly, the tradeoff is weaker, the change in employment if inflation is increased from $0 \%$ to $5 \%$ is reduced by approximately a third for $\eta=2$ and a half for $\eta=5$. Secondly, the curves become noticeably non-linear: as inflation increases, the degree of employment cycling increases and so to does the strength of the labour-supply smoothing effect. Thus the tradeoff gets weaker as inflation increases.

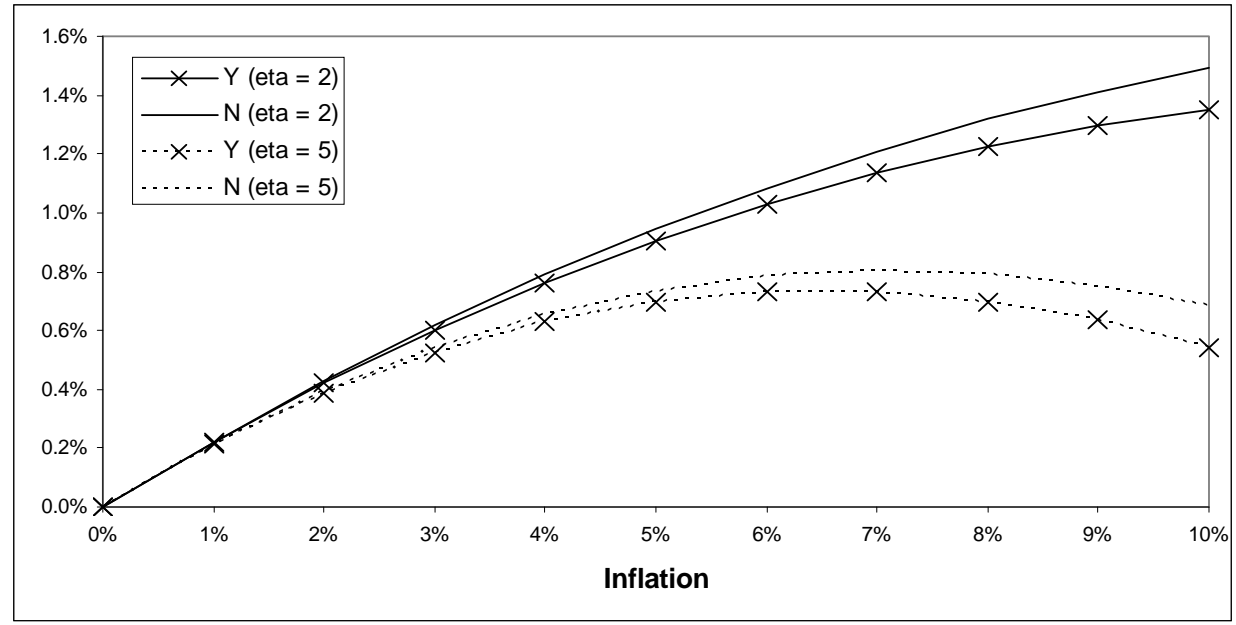

Figure 3: The steady state relation between real variables and inflation: sensitivity to $\eta$

$\mathrm{x}$-axis shows annualized inflation; $\mathrm{y}$-axis percent deviations of real variables from their values at zero-inflation

The parameter $\theta$ measures the degree of substitutability between different labour types in the firm's production function. Low $\theta$ means that labour types are poor substitutes; high $\theta$ means that they are good substitutes. Increasing $\theta$ has three effects. First, different labour types become closer substitutes and thus a given amount of employment cycling is associated with higher output. In other words, holding the degree of employment cycling constant, an increase in $\theta$ raises output. Second, an increase in $\theta$ induces the firm to raise employment cycling,

\footnotetext{
${ }^{14}$ We have also made assumptions about technology and preferences. If we allow the production function to show diminishing returns to aggregate labour, the effect on employment is unchanged but output responds more weakly. Using a power function for labour with an exponent of 0.6 reduces the response of output in our baseline calibration by roughly one half.
} 
since it is now less costly to substitute among labour types over the contract period. For a given level of aggregate employment, an increase in employment cycling leads to a fall in output, since different labour types are imperfect substitutes. For the above calibrations of the other parameters, it turns out that for all but very low rates of inflation, the second effect dominates the first and the output curve lies further below the employment curve as $\theta$ increases. Thirdly, the greater is the degree of cycling, the stronger is the discounting effect so the lower is the wage and the higher the level of employment and output for a given level of inflation.

Table 2 shows the effects of a $1 \%$ increase in inflation on output and employment. Because of the non-linear nature of the relation, we show the effect starting from two base values of $2 \%$ inflation and $6 \%$ inflation.

\section{Table 2: Sensitivity to the elasticity of substitution between labour} types $\theta$

Change in real variables from an increase in steady state inflation

\begin{tabular}{|l|l|l|l|l|}
\hline & \multicolumn{2}{|l|}{$\pi$ increases from $2 \%$ to $3 \%$} & \multicolumn{2}{|c|}{$\pi$ increases from $6 \%$ to $7 \%$} \\
\hline$\theta$ & Employment & Output & Employment & Output \\
\hline 1.01 & $0.04 \%$ & $0.04 \%$ & $0.04 \%$ & $0.04 \%$ \\
\hline 2 & $0.09 \%$ & $0.08 \%$ & $0.08 \%$ & $0.07 \%$ \\
\hline 5 & $0.21 \%$ & $0.20 \%$ & $0.17 \%$ & $0.15 \%$ \\
\hline 10 & $0.37 \%$ & $0.35 \%$ & $0.23 \%$ & $0.19 \%$ \\
\hline
\end{tabular}

The literature gives little guide as to what value of $\theta$ is appropriate for aggregate data. The elasticity of substitution between labour types defined by occupations and seniority may be low in some instances, but economy-wide occupational unions are rare, while seniority-based unions are absent. In most market economies nowadays, wage-setting cohorts usually comprise a wide rage of occupations and seniority scales, so that the cohorts are presumably highly substitutable for one another. Thus high values of $\theta$, e.g. values well above 5 , appear plausible in our analytical setting.

Table 3 shows how the slope of the tradeoff varies with the contract length. As the contract length increases, our effect becomes more pronounced, since the degree of employment variation over the contract becomes greater. In response to this, the labour supply smoothing effect becomes stronger at higher levels of inflation, and so the relation becomes more non-linear. 
Table 3: Sensitivity to the contract length

Change in real variables from an increase in steady state inflation

\begin{tabular}{|l|l|l|l|l|}
\hline & \multicolumn{3}{|l|}{$\pi$ increases from $2 \%$ to $3 \%$} & \multicolumn{2}{|l|}{$\pi$ increases from $6 \%$ to $\%$} \\
\hline Contract (years) & Employment & Output & Employment & Output \\
\hline 0.5 & $0.10 \%$ & $0.10 \%$ & $0.09 \%$ & $0.09 \%$ \\
\hline 1 & $0.21 \%$ & $0.20 \%$ & $0.17 \%$ & $0.15 \%$ \\
\hline 1.5 & $0.30 \%$ & $0.28 \%$ & $0.22 \%$ & $0.17 \%$ \\
\hline 2 & $0.39 \%$ & $0.36 \%$ & $0.24 \%$ & $0.17 \%$ \\
\hline
\end{tabular}

It is worth noting that our choice of parameters is based on estimates in the literature, rather than derived from a relationship between output / employment and inflation that we estimate ourselves. Since this relationship can be estimated in a wide variety of ways and is subject to considerable, ongoing controversy, we deem it to be wiser - given our present state of knowledge - to present our results for a wide range of plausible values for the relevant parameter values. This has been done above and we have seen that a positive long-run relation between inflation and output/employment emerges over this wide range of values, at moderate inflation rates.

\section{Discussion}

In this section we discuss the validity of our underlying assumptions and draw out some empirical implications of our model. Apart from hyperbolic discounting, the evidence for which we have discussed above, our central results rest on two key assumptions: that wages are set annually in nominal terms, and that within this contract period of one year there is no indexation.

When thinking about the nature of wage contracts it is important to distinguish between unionised and non-unionised workers. Taylor (1998), reviewing the direct empirical evidence for the unionised sector in the US, cites a large number of studies that suggests that annual contracts are the most common length of wage setting interval. The wide variation across countries is captured by Groth and Johansson (2004) who update the study of Bruno and Sachs (1985) with data from 1985 - 1995. They assign countries an index which takes a value of 0 if the average length of union contract is a year or less, 1 if it is from 1 - 3 years and 2 if it is greater than 3 years. The mean of this index across OECD countries was 0.94 for 1985 - 1995, suggesting a mean contract length greater than a year.

There is much less evidence on the non-unionised sector, partly because the most common source of data are panel data sets (the PSID for the US, or the 
BHPS for the UK) which typically collect their data annually so necessarily miss any sub-annual wage setting. However there does seem a consensus in the literature that most wages are set annually. For example, Taylor (1998), for the US, writes that "setting nominal wages at a fixed level for more than several quarters and usually for as long as a year appears to be just as prevalent for workers who are not in unions, or do not have formal employment contracts, as for union workers with employment contracts". Smith (2000), referring to the UK, notes that "pay negotiation in the United Kingdom typically occur at annual intervals, and pay awards are often made every 12 months even for workers who are not covered by collective bargaining" and Brown et al (2004) state that the annual wage settlement is "the principal source of pay change for most employees in Britain". This is consonant with estimates of the degree of wage stickiness (reviewed in Taylor, 1998)) using aggregate data which typically find the average length of time between wage changes to be greater than one year.

Because we assume the length of nominal contracts is fixed at one year while we vary inflation from $0 \%$ to $10 \%$ our model is subject to a version of the Lucas critique. Wouldn't agents change their wage setting behaviour as steady state inflation varies? So an important empirical question is the degree to which the contract period changes with steady state inflation. Taylor (1998) writes than the average contract period fell to one year (our baseline value) during the great inflation of the 1970s, when average inflation was well above the range we consider in this paper. Looking across the OECD, Groth and Johansson (2004) find their index variable was 0.78 in the period $1975-85$, still consistent with an average contract length above a year, and rose to 0.94 in the next ten years when average inflation was lower. So this suggests that modelling nominal contracts as fixed at one year over a range of inflation from $0-10 \%$ as we do in this paper is, if anything, a conservative assumption and we could expect contracts to be longer now average inflation is low.

Can we understand this surprising rigidity of the contract length theoretically? We have analyzed this case extensively in previous work (Graham and Snower, 2004). There, rather than treating the contract period as exogenous, we allow households to choose the length of their wage contract period, assuming that there is a fixed cost to changing wages. To calibrate this fixed cost we assume that wages are set for one year at an inflation rate of $5 \%$, on the basis that this is the average level of US inflation over the past 20 years. We find the fixed cost is large. This should not be very surprising since it represents much more than a negotiation cost (e.g. the cost of the time spent negotiating, 
the expected cost of a breakdown in negotiations, etc.), as wage adjustments are typically accompanied by performance and salary reviews.

Because this cost is large, the effect of endogenising the contract length was minimal over a range of $0 \%-10 \%$ inflation, though as inflation increases above $10 \%$ the effect may become rapidly larger. Further, the effect of endogenisation is to strengthen the tradeoff between inflation and real variables for rates of inflation less than the reference level of $5 \%$. Since the costs of inflation decrease with inflation, the household is less willing to pay the fixed cost so the contract period lengthens and the tradeoffs become stronger.

Our assumption of Taylor contracts, without intra-contract indexation, instead of Fisher contracts, is similarly open to the Lucas critique. First note that our model of annual nominal contracts nests annual indexation since wages are optimally reset each year. Only indexation within the annual contract period would affect our results. The empirical evidence on indexation is striking, Card (1986), writing about a period when average inflation was well over the top of the range we consider, writes that "perhaps no more than $10 \%$ of all US workers are covered by cost-of-living provisions". This surprising result is because indexation is only observed in union contracts, and, as Card (1983) reports, only in around $60 \%$ of these, and "escalation provisions are rare in the non-union sector". Further, while one can find evidence of quarterly COLA's, the vast majority seem to be annual (Kaufman and Woglom, 1986, Vroman, 1985). More recently, Christofides and Leung (2003), looking at Canadian data from 1976 - 1999, write that "very few contracts contain COLA clauses".

So while wage indexation is a feature of very high inflation rates (Marinakis, 1997) it seems largely absent over the range of inflation we consider. The decision of whether to index or not is very similar to the choice of contract length, and most models that attempt to explain why indexation is not observed (e.g. Ball, 1988. A general review of such models can be found in Calmfors and Johansson, 2002) assume indexation has a fixed cost. Exceptions are Danziger (1988) and Mukerji and Tallon (2004) who show that, if agents are uncertainty averse, they will choose not to index wage contracts even if there are no fixed costs of doing so.

\section{Concluding comments}

We have shown that the interaction of staggered wage contracts with hyperbolic discounting leads to inflation having significant long run effects on real variables. What are the implications for monetary policy and macroeconomic analysis? We 
address these in turn.

As to the optimal inflation rate, first note that output at zero inflation is not first-best optimal due to imperfect competition. As inflation increases, output (and hence consumption) and employment increase, and real money balances fall (as a consequence of the inflation tax). The first increases the utility of households; the second and third decrease it. As the nominal interest rate tends to zero, the third effect dominates giving the Friedman rule. For positive rates of inflation, the relative magnitude of these three effects will depend on the calibration of the model. We leave a detailed analysis of implications of our model for monetary policy for future work.

According to the new Neoclassical Synthesis, unemployment can be divided into structural and cyclical components, where structural unemployment or the NAIRU depends on supply-side factors such as productivity growth and the degree of imperfect competition, while cyclical unemployment depends on demandside factors such as those associated with monetary policy swings. If we define the Phillips curve as the relation between inflation and real macro activity that results from changes in monetary policy, then the new Neoclassical Synthesis implies that the Phillips curve tradeoff exists in the short-run but not in the long-run. This approach suggested that demand- and supply-side shocks could be distinguished econometrically by examining whether they were short- or longlived, see, for example, Blanchard and Quah (1989). Our analysis calls these views into question. If monetary policy can have long-term effects on real variables, unemployment cannot be decomposed into cyclical and structural components; the concept of a NAIRU needs to be reconsidered. 


\section{References}

Ahmed, Shaghil, and John H. Rogers (1998), "Inflation and the Great Ratios: Long-Term Evidence from the U.S.," International Finance Discussion Paper No. 628 , October.

Akerlof, George W. (1991), "Procrastination and Obedience," American Economic Review, Papers and Proceedings, 1-19.

Akerlof, George A, William T Dickens and George L Perry, (1996), "The Macroeconomics of Low Inflation", Brookings Papers on Economic Activity 1, pp.1-59.

Akerlof, G. A., W.T Dickens, W.L. Perry, (2000). Near rational wage and price setting and the long-run Phillips curve, Brookings Papers on Economic Activity $1,1-60$.

Ainslie, George W. (1992), Picoeconomics, Cambridge: Cambridge University Press.

Ascari, Guido, (1998), "Superneutrality of money in staggered wage-setting models", Macroeconomic Dynamics 2, pp.383-400.

Ascari, G., (2000). Optimising agents, staggered wages and persistence in the real effects of monetary shocks, Economic Journal 110, July, 664-686.

Ascari, Guido, (2003), "Staggered Price and Trend Inflation: Some Nuisances", Review of Economic Dynamics, 7, pp. 642-667.

Bakhshi, Hasan, Pablo Burriel-Llombart, Hashmat Khan and Barbara Rudolf, (2003), "Endogenous price stickiness, trend inflation, and the New Keynesian Phillips curve", Bank of England Working Paper 191.

Ball, L. (1988). Is equilibrium indexation efficient? , Quarterly Journal of Economics, vol. 103(2),pp. 299-311.

Ball, L, (1997), "Disinflation and the NAIRU" in Romer, C and D Romer (eds), "Reducing inflation: motivation and strategy", University of Chicago Press, Chicago

Ball, L, (1999) "Aggregate demand and long run unemployment", Brookings Papers on Economic Activity 2, pp 189 - 251

Barro, Robert J, (1999), "Ramsey Meets Laibson In The Neoclassical Growth Model", Quarterly Journal of Economics 114 (4), pp.1125-1152.

Benabou, Roland \& Konieczny, Jerzy D, (1994). "On Inflation and Output with Costly Price Changes: A Simple Unifying Result," American Economic Review, vol. 84(1), pages 290-97 
Benabou, Roland, and Jean Tirole (2002), "Self-Knowledge and Self-Regulation: An Economic Approach," in The Psychology of Economic Decisions: Volume One: Rationality and Well-Being, I, Brocas and Juan Carrillo, eds., Oxford University Press, 137-167.

Benabou, Roland, and Jean Tirole (2004), "Willpower and Personal Rules," Journal of Political Economy, August, forthcoming.

Blanchard, Olivier and Danny Quah, (1989), "The dynamic effects of aggregate demand and supply disturbances", American Economic Review 79 (4), pp.655673.

Blanchard, Olivier and Stanley Fischer, (1989), "Lectures on macroeconomics", Massachusetts Institute of Technology.

Brown, Donna, Peter Ingram and Jonathan Wadsworth, (2004). "Everyone's A Winner? Union Effects on Persistence in Private Sector Wage Settlements: Longitudinal Evidence from Britain," Department of Economics Discussion Papers 1104, Department of Economics, University of Surrey

Bruno, M and Jeffery D Sachs, (1985), "The economics of worldwide stagflation", Blackwell, Oxford.

Bullard, James \& Keating, John W., (1995). "The long-run relationship between inflation and output in postwar economies," Journal of Monetary Economics, vol. 36(3), pages $477-496$.

Calmfors, Lars and Johansson, Asa, (2002)"Nominal Wage Flexibility, Wage Indexation and Monetary Union", CESifo Working Paper Series No. 761

Card, David (1983), "Cost of living escalators in major union contracts", Industrial and Labour Relations Review, 37, 34 - 48

Card, David, (1986). "An Empirical Model of Wage Indexation Provisions in Union Contracts," Journal of Political Economy, vol. 94(3), pages S144-75

Carrillo, Juan, and Thomas Marriotti (2000), "Strategic Ignorance as a SelfDisciplining Device," Review of Economic Studies, forthcoming.

Chari, V V, Patrick J Kehoe and Ellen McGrattan, (1996), "Sticky price models of the business cycle: can the contract multiplier solve the persistence problem", National Bureau of Economic Research Working Paper 5809.

Christofides, Louis N. and Man Tuen Leung, (2003). "Nominal Wage Rigidity in Contract Data: A Parametric Approach," Economica, vol. 70(280), pages 619-638

Chung, Shin-Ho, Richard J. Herrnstein (1961), "Relative and Absolute Strengths of Response as a Function of Frequency of Reinforcement," Journal of the Experimental Analysis of Animal Behavior, 4, 267-272. 
Coenen, G.; Orphanides and Wieland, V., (2004), "Price Stability and Monetary Policy Effectiveness when Nominal Interest Rates are Bounded at Zero", Advances in Macroeconomics, 4(1), 1187-1187.

Danziger, L., 1988. Real shocks, efficient risk sharing, and the duration of labor contracts, Quarterly Journal of Economics 103(2), May, 435-440.

Diamond, Peter, and Botond Koszegi (2003), "Quasi-Hyperbolic Discounting and Retirement", Journal of Public Economics, 87(9-10), pp. 1839-1872.

Dixit, Avinash K and Joseph E Stiglitz, (1977), "Monopolistic Competition and optimum product diversity", American Economic Review 67 (3), pp.297-308.

Dolado, J. J., López-Salido, J. D., Vega, J. L., 2000. "Spanish unemployment and inflation persistence: are there Phillips trade-offs?", Spanish Economic Review 2, 267-291.

Erceg, Christopher J, Dale W Henderson and Andrew T Levin, (2000), "Optimal monetary policy with staggered wage and price contracts", Journal of Monetary Economics 46, pp.281-313.

Ericsson, Neil, John Irons, and Ralph Tryon (2001), "Output and Inflation in the Long Run," Journal of Applied Econometrics, 16, 241-253.

Fair, R. C., 2000. "Testing the NAIRU model for the United States", The Review of Economics and Statistics, 82 (1), February, 64-71.

Fishburn, Peter C., and Ariel Rubinstein (1982), "Time Preference," International Economic Review, 23, April, 287-309.

Fisher, M., Seater, J., 1993. Long-run neutrality and superneutrality in an ARIMA framework, A"merican Economic Review, 83, 402-415.

Gottschalk, Jan, and Ulrich Fritsche (2005), "The New Keynesian Model and the Long-Run Vertical Phillips Curve: Does It Hold for Germany?", DIW Discussion Paper No. 521, Nov., Berlin.

Graham, Liam and Dennis J Snower, (2004), "The real effects of money growth in dynamic general equilibrium", European Central Bank Working Paper No 412

Groth, Charlotta \& Johansson, Asa, (2004). "Bargaining structure and nominal wage flexibility," European Economic Review, Elsevier, vol. 48(6), pages 13491365 .

Holden, S., (2003), "Wage-setting under different monetary regimes", Economica 70(278), 251-265.

Huang, KXD and Z Liu, (2002), "Staggered price setting, staggered wage setting and business cycle persistence", Journal of Monetary Economics 49, pp.405-433.

Huang, KXD, Z Liu and L. Phaneuf (2004), "Why does the cyclical behavior of real wages change over time?", American Economic Review 94 (4), pp. 836-856 
Hughes-Hallet, A.J., (2000), "Aggregate Phillips curves are not always vertical: heterogeneity and mismatch in multiregion or multisector economies", Macroeconomic Dynamics 4, 534-546.

Karanassou, Marika, Hector Sala, and Dennis J. Snower (2003), "The European Phillips Curve: Does the NAIRU Exist?" Applied Economics Quarterly, 2003, 49(2), 93-121.

Karanassou, Marika, Hector Sala, and Dennis J. Snower (2005), “A Reappraisal of the Inflation-Unemployment Tradeoff," European Journal of Political Economy, 2005, 21(1), 1-32.

Kaufman, Roger T and Geoffrey Woglom (1986), "The Degree of Indexation in Major U.S. Union Contracts", Industrial and Labor Relations Review, Vol. 39, No. 3. (Apr., 1986)

King, Robert G, Charles Plosser and Sergio Rebelo, (1988), "Production, Growth and Business Cycles I: The basic neo-classical model", Journal of Monetary Economics, 21, pp.195-232.

King, R.G., Watson, M.W., 1994. "The post-war U.S. Phillips curve: a revisionist econometric history", Carnegie-Rochester Conference Series on Public Policy 41, $157-219$.

Konieczny, Jerzy (1990), "Inflation, Output and Labor Productivity when Prices are Changed Infrequently," Economica, May, 57(226), 201-218.

Koopmans, Tjalling C. (1960), "Stationary Ordinal Utility and Impatience," Econometrica, 28, Apri, 287-309.

Koustas, Zisimos (1998), "Canadian Evidence on Long-Run Neutrality Propositions," Journal of Macroeconomics, 20(2), 397-411.

Koustas, Zisimos, and W. Veloce (1996), "Unemployment Hysteresis in Canada: An Approach Based on Long-Memory Time-Series Models," Applied Economics, $28,823-831$.

Koutas, Zisimos and Apostolos Serletis (2003), "Long-Run Phillips-Type Tradeoffs in European Union Countries," Economic Modelling, 20, 679-701.

Kuran, Timur (1986), "Price Adjustment Costs, Anticipated Inflation and Output," Quarterly Journal of Economics, May, 101(2), 407-418.

Laibson, David (1996), "Hyperbolic Discount Functions, Undersaving, and Savings Policy," NBER Working No. 5635, June.

Laibson, David, Andrea Repetto, and Jeremy Tobacman (2001), "A Debt Puzzle," mimeo.

Loewenstein, George, and Drazen Prelec (1992), Anomalies in Intertemporal Choice: Evidence and an Interpretation," Quarterly Journal of Economics, 57(2), 573-598. 
Loewenstein, George and R. Thaler (1989), "Anomalies: Intertemporal Choice," Journal of Economic Perspectives, 3, 181-193.

Lundberg, Per, and Hans Sacklen (2001), "Is There a Long-Run UnemploymentInflation Tradeoff in Sweden?" FIEF Working Paper No. 173.

Mankiw, N Gregory, (2001). "The Inexorable and Mysterious Tradeoff between Inflation and Unemployment," Economic Journal, vol. 111(471), pages C45-61

Marinakis, Andrés E (1997), "Wage policy in high inflation countries: The role of indexation in Latin America during the 1980s", Journal of Economic Studies, 24 (6) pp $356-378$.

Mukerji, Sujoy and Jean-Marc Tallon, (2004), "Ambiguity aversion and the absence of wage indexation", Journal of Monetary Economics 51 (2004) 653-670

Naish, Howard (1986), "Price Adjustment Costs and the Output-Inflation Tradeoff," Economica, May, 53(210), 219-230.

O’Donoghou, Ted, and Matthew Rabin (1999a), "Doing it Now or Later," American Economic Review, 89(1), 103-124.

O'Donoghou, Ted, and Matthew Rabin (1999b), "Incentives for Procrastinators," Quarterly Journal of Economics, 114(3), 769-816.

Orphanides, A. and Robert M. Solow (1990), "Money, Inflation and Growth," Handbook of Monetary Economics, ed. by B.M. Friedman and F.H. Hahn, Amsterdam: North-Holland.

Phillips, A W, (1958), "The Relation between Unemployment and the Rate of Change of Money Wage Rates in the United Kingdom, 1861-1957", Economia 25 (100), pp.283-299.

Samuelson, Paul A and Robert M Solow, (1960), "Analytical Aspects of AntiInflation Policy", AEA Papers and Proceedings 50 (2), pp.177-194.

Sidrauski, M. (1967), "Inflation and Economic Growth," Journal of Political Economy, 75, 796-810.

Schreiber, Sven, and Jürgen Wolters (2005), "The Long-Run Phillips Curve Revisited: Is the NAIRU Framework Data-Consistent?" mimeo.

Smith, Jennifer C, (2000). "Nominal Wage Rigidity in the United Kingdom," Economic Journal, vol. 110(462), pages C176-95

Strotz, Robert H. (1956), "Myopia and Inconsistency in Dynamic Utility Maximization," Review of Economic Studies, 23, 165-180.

Taylor, John, (1979), "Staggered Wage Setting in a Macro Model", American Economic Review 69 (2), pp.108-113. 
Taylor, John, (1998), "Staggered price and wage setting in macroeconomics", National Bureau of Economic Research Working Paper 6754.

Vroman, Wayne (1985), "Cost-of-Living Escalators and Price-Wage Linkages in the U.S. Economy,1968-1980", Industrial and Labor Relations Review, Vol. 38, No. 2., pp. 225-235.

Woodford, Michael, (2003), "Interest and prices", Princeton University Press, Princeton 